\title{
K některým aspektům ztvárnění unisona a jeho metamorfizacím ve vybrané operní literatuře 2. pol. 19. a 1. pol. 20. století
}

\section{Some Aspects of Unisono Rendering and Its Metamorphisms in Selected Opera Literature of the Second Half of the 19th and First Half of the 20th Century}

Karel Dichtl / k.dichtl@seznam.cz

Private researcher, Velešín, CZ

\begin{abstract}
The text deals with the systematization of unison profilations in selected opera literature of the second half of the 19th and the first half of the 20th century. In general, Unisono thus creates an element of compositional sophistication. From a methodological point of view, it is possible to point out the systematization of unison profiles and observe the specification in the use of this composition technique. It is also possible to observe the aspect of polar sound unison coloring in connection with the original composition concept of individual composers.
\end{abstract}

\section{Keywords}

unisono, opera, systematization, functionality, originality 


\section{Úvod}

Unisonová profilace v operní literatuře 2. pol. 19. a 1. polovině 20. století vytváří širokou škálu dramatických a lyrických intonací. Modelace unisonových partií tak v řadě operní literatury sledovaného období profituje na bázi svérázné vybroušenosti, originality a nabývá polarit od poloh jemné lyrizace až k dramaticky vypjatým korelacím. Především je nutno uvést fakt originality unisona v kompozičním odkazu mnohých skladatelských osobností. Půvabné lyrizace s jemně protkanou sonoristikou naplňuje hledisko emocionální působivosti. Lyrizace nabývá poloh v četných augmentacích tématu, či naplňuje funkci podmanivé pejzáže lehkosti, ladnosti, či bohaté zvukové zabarvenosti. Lze konstatovat, že dílčí polohy unisona nabývají na široké škále proměnlivosti a variability hudební výrazovosti.

\section{Příklady unisonových profilací}

Zcela originální unisonové profilace shledáváme např́klad v číslových úsecích Verdiho operní literatury. V kontextu hédoničnosti Verdi obratně karikakuje tematickou práci v četných hypallage intonačních postupech například ve finální ploše opery Don Carlos. ${ }^{1}$ Lyrizace unisonových partií nalézá svou identitu v neotřelé kantabilizaci ve finální ploše Straussovy opery Egyptská Helena v konsonantní unisonové melodizaci závěrečného dvojzpěvu Heleny a Menela. Jemnost stylistické unisonové pointilističnosti provází př́klad massenetovské operní literatury a sice v příslušných pasážích opery Manon. ${ }^{2}$ Massenet koncipuje své unisonové partie v citově exaltovaných polohách opery Werther, a sice ve 2. scéně 3. jednání ve výstupech Charlotty a hlavního hrdiny. Sentiment a nostalgie provází unisonové partie též v Massenetově opeře Cendrillon, například ve 2. scéně 2. dějství v křehkosti tutti instrumentálních profilací v sólovém výstupu hlavní hrdinky díla. Poetizaci unisonových partií lze spatřit ve Feldově opeře Poštácká pohádka v dolce jímavých kreacích ve 4. scéně 1 . jednání v taktech číslo 28-34, 59-62 a 76-82. Též Bartókův Modrovousưv hrad zavání lyrickým půvabem v unisonech smyčců a dechů komplementující zpěv hlavního hrdiny ve 3. scéně 1 . jednání taktech číslo 28-34 a 72-78. Výrazná pointilističnost a procítěnost stimuluje vitalitu unisona ve Straussových mytologémech Dafné a Danaina láska $a^{3}$ ve 4 . scéně opery Dafné v 1. jednání v pitoresknosti příslušných profilací v partu hlavní hrdinky v taktech číslo 16-20 a 47-54. Zvuková barva též koresponduje v půvabných unisonových lyrizacích v Pucciniho operách Bohéma ${ }^{4}$ ve 2 . jednání 5 . scéně

1 O unisonu blíže GARTIOUX, Hervé. Giuseppe Verdi: Don Carlos. Heilbronn: Galland, 1997, s. 19-20.

2 Unisonové profilace v opeře popisuje též BOUILHOL, Eliane. Massenet - son rôle dans l'évolution du théâtre musical. Saint-Étienne: s. n., 1969, s. 58-59.

3 Analýzou unisona se zabývá ABERT, Anna Amalie. Richard Strauss. Die Opern. Velber: Friedrich, 1972, s. $68-70$.

4 O unisonu v této opeře též CAVOLI, Alfio. Puccini in Maremma. Roma: Scipioni, 1990, s. 108-109. 
taktech číslo 28-36 a 79-82. Též veristická operní literatura specifikuje individualitu unisonových pasáží v neobyčejné dramatizaci v opeře Turandot v závěrečných kreacích hlavní hrdinky. Zcela osobitých poloh nabývá unisono v závěrečné apoteóze Minie a Johnsona v Pucciniho opeře Děvče ze Zlatého západu, či Giordanově operním výtvoru Andrea Chenier. Dále ostře vygradovaná unisona lze identifikovat ve Ferrariho opeře Sly v dramatických polohách ve 4 . scéně 2 . jednání ve forteových relacích osminových hodnot v šestiosminovém taktu. Unisono tak vytváří complexus intenzivní gradační modelace, inspirační modus bohaté instrumentální diferenciace jednotlivých hlasových partií a současně extenzifikuje variabilitu kompoziční tvárnosti a vyhraněnosti. Exclamatio unisonovou profilaci naplňuje ve svém díle E. Humperdinck v jeho výtvoru Perniková chaloupka a sice ve 3. scéně 1 . jednání a 5 . scéně 2. dějství. Též stenastické rétorické figury identifikujeme v modelaci unisona ve Dvořákově opeře Čert a Káča $a^{5}$ v partu matky prohlubující dramatickou impulsivnost a tvárnost. Zajímavě koncipuje unisono G. Verdi v opeře Maškarni ples ${ }^{6}$ a sice v duetu Richarda a Amélie ve 2. jednání při vedení oktávových poloh jednotlivých hlasových partií v části A, či v tacetu instrumentálních komplementárních figurací v části B. Další perfekcionismus unisonové techniky představuje např́ílad duet Otella a Desdemony v závěru 1. jednání Verdiho opery Otello v syrrytmikách a vyklenutí melodiky do velké sexty v části A, či v lyrické poddajnosti smyčců podbarvujících sólové hlasové proporce v části B. Verdi zde tvaruje vertikalizaci v augmentačních proporcích v celém taktu v celých notových hodnotách v Ges Dur. Příznačnou pastoralitu ve vedení unisonové linie představuje instrumentální plasticita pianového odstínu hobojů a smyčců v Ces Dur se sopránovými partiemi sólového hlasu v Gounodově opeře Mireille a sice ve 4. scéně 2. jednání taktech číslo 19-22 a 34-41. Výrazné proměny unisonové praktiky dále shledáváme v opeře Mese Mariano Umberta Giordana od poloh sensitivní kantability v 1. jednání k dramatickým pulsacím se subjektivní dramatickou vyhroceností ve 3. dějství kompozice.

\section{Estetický horizont}

Z estetického hlediska lze obecně upozornit na erudici krásy smyslového půvabu, jasu, rozkoše a zvukové jemnosti. Unisono tak profiluje amabilitu lyrické hloubky, dramatické koncentrovanosti a instrumentální plasticity. Estetično unisonových profilací tak prohlubuje dokonalost, působivost, či poddajnost krásyplného prožitku. Připomenout lze Herderovu vznešenost a eleganci, či neoplatónskou stylovou čistotu v půvabných

5 K analytickým otázkách díla viz DICHTL, Karel. Muzikologické reflexe 2. České Budějovice: Protisk, 2017, s. $35-49$.

6 O unisonových profilacích ve Verdiho operní literatuře viz DICHTL, Karel. Muzikologické reflexe 2, op. cit., s. 29.

7 O unisonu v této opeře viz také LOCKE, Ralph P. Reflections on Orientalism in Opera and Musical Theater. The Opera Quarterly, roč. 10, 1993, č. 1, s. 48-64. 
sonorizacích a harmonizacích. Technika unisona tak naplňuje úkaz estetických kategorizací oslnivosti, elegance, vytř́benosti a vkusnosti.

\section{Filozofický aspekt}

Z filosofického hlediska atributizujeme poznání unisona z pozice husserleovského transcendentna v dílčích apoteózách a mystičnosti syžetu, či Schelerově citové etiky s podstatou emoční senzualizacce a procítěnosti. Ze strukturálního hlediska lze poukázat na čistotu stylové pregnance $\mathrm{v}$ systémovosti a řádovosti intelektuálního poznání $\mathrm{v}$ predispozici derridovské strukturalistické čistoty.

\section{Stylistická rozmanitost}

Intermitentní unisonovou stylistiku dokumentujeme na př́kladu 3. scény 2. jednání ve Verdiho opeře Síla osudu, kde skladatel vrství v 1. melodickém pásmu v intonačním račím postupu jednotlivé hlasové proporce a následují čvrtové pomlky, na něž navazuje 2. melodický blok v hypallage postupech altů a sopránů ve vokální složce a v basu v instrumentálních komplementacích v celém taktu v půlových notových hodnotách v Cis Dur v taktech číslo 46-50, 59-64 a 70-76.

\section{Unisono a jeho metamorfizace}

Výraznou sonoristickou metamorfizaci unisona představuje dále 2. scéna 2. jednání opery Don Carlos v duetu Alžběty a Dona Carlose v počáteční lyrizaci tématu ve smyčcích $\mathrm{v}$ části A, či v allegrové ploše tutti zvukové profilace v části B v taktech číslo 1-19 a 22-29. Verdi zde obratně využívá zvukových kombinací v průzračných spektrech kvartsextakordů v Es Dur a allegrových segmentech alterovaných septakordů na dominantě v části $\mathrm{B}$ $\mathrm{v}$ c moll.

\section{Systematizace unisonových relací}

Unisonové profilace tak lze obecně identifikovat v:

v př́islušných legátizovaných melodických obloucích,

v komplementárních figuracích,

v leitmotivických tendencích,

$\mathrm{v}$ mezivětách, 
v instrumentálních interpolacích,

$\mathrm{v}$ augmentacích,

v hyperbatonikách a hyperbolikách,

v katarzních finálních úsecích,

v subsystematikách,

$\mathrm{v}$ intermitencích,

v sólových vokálních výstupech s tacetem komplementárních instrumentálních figuracích.

\section{Variety unisonového ztvárnění}

Unisono skladatelé koncipují v následujících varietách:

v unisonovém vedení sólových vokálních hlasů v komplementaci instrumentálních figur nejčastěji v basu,

v unisonovém vedení hlasů v instrumentálních komplementacích nad protihlasy ve vokální složce,

v celistvosti unisonové profilace jak ve vokálních, tak v instrumentálních proporcích, v díčích unisonových profilacích v noematizacích,

při schematoides principu při slévání jednotlivých hlasových partií nejčastěji na tónice, subdominantě a dominantě,

ve sborových echo stylizacích,

v interpolativních segmentech ve variačních instrumentálních profilacích,

v climactikách vokálních ploch komplementovaných unisonovými profilacemi v orchestru, ve variačních úsecích ve vokálech nad unisonem v basu,

$\mathrm{v}$ unisonu ve vokálech nad kontrapunktickými variacemi v basu,

ve vokálním unisonu nad imitací lidového dvojhlasu v basu,

v koloratuře ve vokálech nad unisonem $\mathrm{v}$ basu,

v legátizacích vokálů nad staccatizacemi v basu,

v pichlavých sforzatech ve vokálech nad ligaturami v basu.

\section{Vyvažování jednotlivých hlasových spekter}

Příznačným rysem unisonových praktik se jeví parembolické vyvažování jednotlivých hlasových proporcí v komplementárních figurách $\mathrm{v}$ basu v parembole čistých intervalových postupů při procesu vyplňování prázdných míst mezi jednotlivými hlasovými spektry. Faktura tak nabývá v mnohých kompozicích na rituálu sonoristické vyváženosti při slad’ování jednotlivých zvukových odstínů. Toto tvrzení lze dokumentovat na principu unisonových technik v opeře Fedora U. Giordana, kde autor parembolizuje alty a soprány čistou kvartou a kvintou $\mathrm{v}$ basových komplementacích $\mathrm{v}$ celém taktu v půlových notových hodnotách ve 2 . scéně 2 . jednání opery v taktech číslo 36-41 a 59-63. 


\section{Gnósis dynamických, rytmických, tempových a harmonických odstínů}

Zabýváme-li se dále poznáním shora uvedených odstínů, lze poukázat na výraznou proměnlivost hudebně výrazových prostředků. Bohaté variety komplementárních figurací v orchestru naplňují horizont harmonické vybroušenosti v modelaci četných protihlasů, imitací, prodlev, zahuštování faktury alterovanými septakordy, průchodnými tóny, patternovými cirkulacemi, či intenzivně bohatě tvarovanou vokální složkou nad unisonovými profilacemi komplementárních figurací. Vokální linii lze identifikovat v četných parembolikách, multiplicatio extenzivních segmentech, či shora nastíněných metamorfizacích.

Unisono tak sehrává svou úlohu v protikladných komoditách uplatněných hudebně výrazových prostředků.

\section{Závěr}

Závěrem tak lze shrnout, že z metodologického hlediska jsme sledovali v této studii systematizací unisonového ztvárnění, jeho metamorfizaci a variabilní profilaci a dospěli jsme ke stanovení konkrétních př́́kladů použití tohoto kompozičního prvku. Poukázali jsme na některé zajímavosti při koncepci unisonové praktiky. Lze tak konstatovat, že unisono se stává v kompozičním procesu výrazným stimulem k modelaci kompoziční svéráznosti, vyhraněnosti a též v operním vývoji námi sledovaného období vytváří základní stavební kámen k tektonické pevnosti a ucelenosti.

\section{Bibliography}

ABERT, Anna Amalie. Richard Strauss. Die Opern. Velber: Friedrich, 1972.

BOUILHOL, Eliane. Massenet - son rôle dans l'évolution du théâtre musical. Saint-Étienne: s. n., 1969.

CAVOLI, Alfio. Puccini in Maremma. Roma: Scipioni, 1990.

DICHTL, Karel. Muzikologické reflexe 2. České Budějovice: Protisk, 2017.

GARTIOUX, Hervé. Giuseppe Verdi: Don Carlos. Heilbronn: Galland, 1997.

LOCKE, Ralph P. Reflections on Orientalism in Opera and Musical Theater. The Opera Quarterly, roč. 10,1993 , č. 1, s. 48-64.

SCHICKLING, Dieter. Giacomo Puccini: Biographie. Stuttgart: DVA, 1989.

SCHNIERER, Miloš. Přehled dějin estetiky. České Budějovice: Jihočeská univerzita, 1997. 